(2010) 1 Jurisprudence 85-104

\title{
Blinded by the Light of Hohfeld: Hobbes's Notion of Liberty
}

\author{
Eleanor Curran*
}

\section{INTRODUCTION}

Hobbes's definition and use of the term 'liberty' has been and continues to be the subject of much debate within Hobbes scholarship. The change in definition from De Cive $^{1}$ to Leviathan ${ }^{2}$ is one such focus of commentary; ${ }^{3}$ another is his purported change in definition between applications of 'liberty' to the state of nature and to civil society. ${ }^{4}$ Other commentators also discuss his use in Leviathan of more than one meaning for the term. ${ }^{5}$ The focus of a recent study is Hobbes's purported rejection of the rich 'republican' traditional understanding of liberty, in order to champion a radically restricted application of the term to mean nothing more than the absence of external impediments to one's actions. ${ }^{6}$ In this article I examine

* Lecturer, Kent Law School, University of Kent, UK. I would like to thank James Lee for his very helpful comments on an earlier draft of this article. I would also like to thank participants at the Jurisprudence Section of the SLS annual conference at Keele University in 2009, where I presented an earlier version of the article, for their interesting comments and suggestions. Finally, I am grateful to the two Jurisprudence referees for their very helpful comments and suggestions.

1 'LIBERTY (to define it) is simply the absence of obstacles to motion; as water contained in a vessel is not free, because the vessel is an obstacle to its flowing away, and it is freed by breaking the vessel'. Thomas Hobbes, De Cive (1647) in On the Citizen (Richard Tuck and Michael Silverthorne ed and trans) (Cambridge University Press, 1998) 111.

2 Hobbes begins Chapter 14 of Leviathan with a similar definition, but adds the word 'externall', as in 'the absence of externall Impediments'; he also adds 'which Impediments, may oft take away part of a mans power to do what hee would; but cannot hinder him from using the power left him, according as his judgement, and reason shall dictate to him'. Thomas Hobbes, Leviathan (CB Macpherson ed) (Pelican, 1968) ch 14, 189.

3 See eg FC Hood, 'The Changes in Hobbes's Definition of Liberty' (1967) 17 Philosophical Quarterly 150.

4 JR Pennock, 'Hobbes's Confusing “Clarity": The Case of Liberty' (1960) 54 American Political Science Review 428.

5 See Michael M Goldsmith, 'Hobbes on Liberty' (1989) II Hobbes Studies 23 for the argument that Hobbes expands the definition to cover freedom from laws and covenants as well as from merely physical impediments; see also Annabel S Brett, Liberty, Right and Nature: Individual Rights in Later Scholastic Thought (Cambridge University Press, 1997) for the argument that Hobbes uses liberty in two different ways that cannot be reconciled. Both arguments are discussed in this article.

6 See Quentin Skinner, Hobbes and Republican Liberty (Cambridge University Press, 2008). 
Hobbes's use of the notion of liberty, paying particular attention to its place in his theory of rights. My argument is that in describing the rights that individuals hold, Hobbes can be seen to be employing the notion of liberty to cover more than the restrictive definition of the absence of external impediments, and that this broader understanding of liberty should not be put down to simple inconsistency on Hobbes's part.

In the second part of the article I consider the Hohfeldian analysis of rights, ${ }^{7}$ and in particular the dominance of the treatment of the notion of a claim as foundational for the notion of a right that, I argue, has been for many a legacy of the application of that analysis. As Jeremy Waldron puts it, 'Hohfeld's claim-right is generally regarded as coming closest to capturing the concept of individual rights used in political morality'. ${ }^{8}$ This is very much the case in Hobbes scholarship as well as in political philosophy more broadly. Jean Hampton, for example, in her justly famous Hobbes and the Social Contract Tradition, ${ }^{9}$ calls on Hohfeld's analysis to discuss Hobbesian rights and says that 'in trying to understand Hobbes's use of the notion of a right ... we must begin by making use of the well-known analysis of this notion by the American legal theorist Wesley Hohfeld'. ${ }^{10}$ She mentions the four categories or notions of right as defined by Hohfeld and then remarks, "The notion of a right as a claim is perhaps the most common and natural concept that the word "right" has been taken to cover'. ${ }^{11}$ And Mathew Kramer, in his penetrating discussion of rights theory 'Rights without Trimmings', ${ }^{12}$ sets out the Hohfeldian view as being that a 'right or claim ... is the legal position created through the imposing of a duty on someone else'. ${ }^{13}$ While he is in the process of providing an exposition of Hohfeld's analytical scheme, Kramer uses the term 'right' in a way that sometimes implies his own acceptance of the notion of a claim as foundational for that of a right.

A couple of examples may help to illustrate this. In turning from discussing Hohfeld's notion of a claim (which term Kramer, following Hohfeld, uses interchangeably with right) to setting out his (Hohfeld's) notion of a liberty, Kramer says that 'one's actions or inactions grounded in liberties are effectively protectedto a considerable extent-by rights that do not pertain specifically to those actions or inactions'. He then reiterates, 'Indeed, in almost every situation outside the Hobbesian state of nature, conduct in accordance with a liberty will receive at least a modicum of protection through a person's basic rights' ${ }^{14}$ Here he could be said to be using 'rights' to mean actual moral or political rights as distinct from liberties, which fall short of being rights proper. This might not signify any more than a tendency

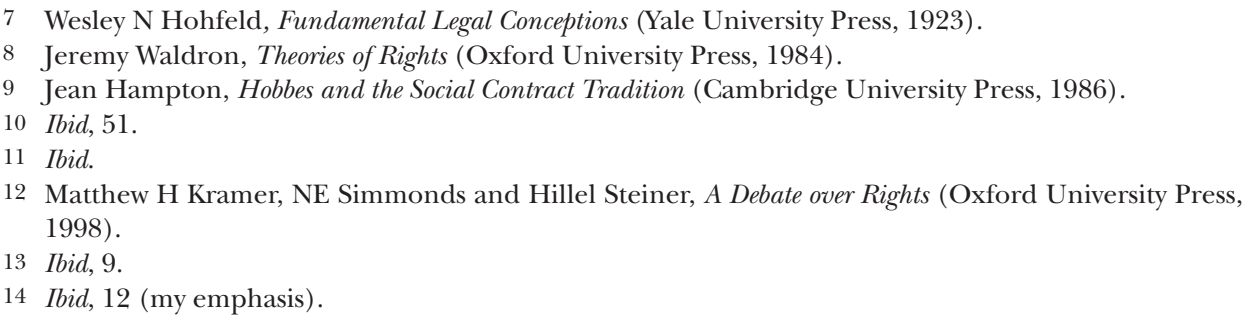


to use the word 'right' to cover both claim and right in a more general sense, however, and Kramer does make it clear that his intention is to remain true to Hohfeld's analysis and not to choose between his categories. But even so, a commentator like Kramer, who purports to make no preference between the four Hohfeldian categories of 'right' (in other words, he accepts that no one of the four categories defines a right any more than the others), does nevertheless, in his use of the language of rights, imply that 'claim' rather than 'liberty' can be substituted for 'right', and therefore implies that it comes closest to our common understanding of a right.

It could be argued that for Kramer, this does not amount to much; and that he is very careful to remain true to Hohfeld's analysis and to treat each category of right as a simple legal position and not to give any one category preference over any other. My other two examples, however, of Waldron and Hampton, do illustrate a tendency, found in many writers, to treat the Hohfeldian claim as coming closest to our common understanding of a moral or political right. The implication of this is that the notion of a claim is foundational for that of a right.

My suggestion, in the second part of the article, is that there may be disadvantages to seeing the notion of a claim as foundational for the notion of a right, and that some of these are thrown into relief by Hobbes's earlier use of the notion of liberty as foundational for the idea of a right. In light of this, it is worth considering whether the notion of liberty might be more effective than that of a claim to ground our notion of a right. Equally, it is worth considering whether using the notion of liberty might be more effective than failing to choose any of Hohfeld's categories as coming closest to our common understanding of a moral or political right.

\section{BACKGROUND}

The notion of liberty is of course central to Hobbes's political theory. Recent work on his understanding of liberty has once again raised the issue of whether and to what extent he intends to restrict the meaning of liberty to the mere 'absence of externall Impediments', ${ }^{15}$ and what implications this has for his relationship to the rich history of 'republican liberty' and to the history of the development of the notion of subjective right in the writings of the scholastics. ${ }^{16}$ Quentin Skinner, developing a longrunning theme of his writing, argues that Hobbes undertakes an 'epoch-making effort to discredit the republican theory of liberty ...' ${ }^{17}$ and that he 'developed this line of argument in conscious reaction to the republican theory of liberty'. ${ }^{18}$

15 Leviathan (n 2) ch 14, 189.

16 See eg Brett (n 5); Matthew H Kramer, 'Freedom, Unfreedom and Skinner's Hobbes' (2001) 9(2) Journal of Political Philosophy 204; Skinner (n 6).

17 Skinner (n 6) 212.

18 Ibid, 211. 
The republican theory of liberty to which Skinner is alluding, is that which 'originated in classical antiquity, and lay at the heart of the Roman republican tradition of public life'. The theory 'was later enshrined in the Digest of Roman law, and still later became associated with the city-republics of Renaissance Italy' ${ }^{19}$ It is a theory of human freedom that sets up a sharp dichotomy between freedom and servitude or slavery. In the Digest this is expressed in an early passage as the contention that 'the chief distinction in the law of persons is that all men are either free or else are slaves'. ${ }^{20}$

The decisive factor in determining freedom or servitude is, according to the theory, whether or not one is subject to the arbitrary will of another. One is either in one's own power or under the power of another. The mere fact of being under the power of another is what reduces one's status from that of free-man to that of slave. The important element to stress here is that one's freedom or liberty is automatically lost once one is under another's power. Republican liberty is characterised by Philip Pettit as 'the ideal of political freedom as non-domination'.21 He argues that there are two themes that distinguish the theory:

First, the argument that a person who is the slave or subject of another is unfree, even if that other never acts against them. And, second, the argument that so far as the law of the land is non-arbitrary ... to that extent it does not itself take away people's freedom. ${ }^{22}$

Skinner draws out the following implication, which is critical for his argument against Hobbes's theory of liberty, as he sees it:

One crucial implication is that liberty can be lost or forfeited even in the absence of any acts of interference. The lack of freedom suffered by slaves is not a consequence of their being hindered in the exercise of their desires. Slaves whose choices happen never to conflict with the will of their master may be able to act without the least interference. They nevertheless remain wholly bereft of their liberty. They remain subject to the will of their master, unable to act according to their own independent will at any time. They are, in other words, not genuine agents at all. ${ }^{23}$

Emphasising, as it does, human liberty as freedom from domination by the arbitrary power of others, rather than merely the freedom from (external) impediments to doing what one has a will to do, does indeed seem strikingly opposed to Hobbes's adoption of such a restricted use of the term.

Skinner's main thesis is that Hobbes deliberately and overtly attacked the republican understanding of political liberty as freedom from the arbitrary power of others and replaced it with his restricted notion of liberty as the absence of external impediments. In doing this Hobbes set in train a new political understanding of liberty as simply a lack of (external) interference. This understanding of liberty is

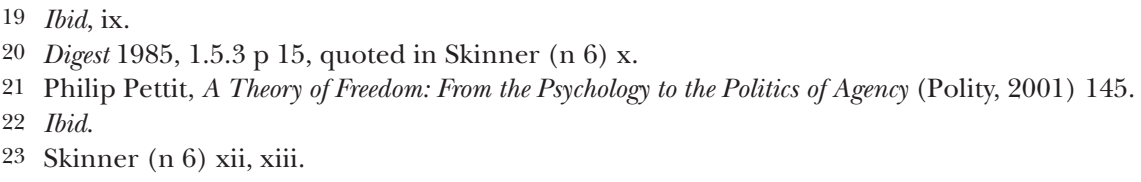


still hugely influential today and is, perhaps, most famously expressed in Isaiah Berlin's notion of 'negative liberty'. ${ }^{24}$ This notion, simply put, is freedom from the interference of others. I am free to walk down the road if no one prevents me from walking down the road or stops me as I walk and prevents me from walking any further. In its political application, negative freedom has usually been seen as the freedom of individuals from undue interference by the state. If I was required by law to produce identity papers, for example, before I was able to walk down the road, then I would not be free in that sense. Or, if women were not allowed to walk unaccompanied in public places, then I would lack this kind of negative freedom. (Berlin, of course, contrasted it with positive freedom, which has often been characterised as 'freedom to' rather than the 'freedom from' of negative liberty and is usually seen, in a political context, as implying an obligation on the state to provide what is required to enable or empower citizens to act freely.) Negative freedom has come to be seen as particularly attached to liberal political theory.

It might be worth repeating here that, according to Skinner's interpretation, Hobbes's notion of liberty is not simple negative liberty, as briefly outlined above, but rather a super-restrictive form of negative liberty, that sees it as comprising nothing more than the literal absence of physical obstacles to what I have a will to do. So, as in the example above, according to Skinner, Hobbes does not think that I lack the liberty to walk down the road if there is a law stating that I must show my identity papers first. It is only if there is a policeman/soldier physically preventing me from walking that I am unfree. Or if I am bound and unable to move, then I am unfree. The law itself cannot make me unfree. Indeed, even a gun pointed at my head does not make me unfree, because I can still choose to walk (and risk being shot). ${ }^{25}$ Now it might be clearer what the political implications are, for such a restrictive understanding of liberty. It means that one could live in a totalitarian state or police state and still, on this account, be 'free'.

The contrast between the classical republican notion of liberty and the modern liberal notion of negative liberty is a fascinating one and raises many questions about the reasons for Hobbes's hostility towards the republican theory of liberty. Unfortunately there is not the space here to discuss this in any detail.

Skinner supports the argument that Hobbes's view of liberty is 'stark in its simplicity', ${ }^{26}$ claiming as it does that 'to be free is simply to be unhindered from moving in accordance with one's natural powers, so that human agents lack freedom of action if and only if some external impediment makes it impossible for them to

24 See Isaiah Berlin, 'Two Concepts of Liberty' in Four Essays on Liberty (Oxford University Press, 1969).

25 As Hobbes says in Chapter 21 of Leviathan, 'LIBERTY, or FREEDOME, signifieth (properly) the absence of Opposition; (by Opposition, I mean externall Impediments of motion); and may be applied no lesse to Irrationall, and Inanimate creatures, than to Rationall. For whatsoever is so tyed, or environed, as it cannot move, but within a certain space, which space is determined by the opposition of some externall body, we say it hath not Liberty to go further. And so of all living creatures, whilst they are imprisoned, or restrained with walls, or chains; ... they are not at Liberty, to move in such manner, as without those externall impediments they would'. Leviathan (n 2) ch 21, 261-2.

26 Skinner (n 6) 211. 
perform an action that would otherwise be within their powers' ${ }^{27}$ Yet he traces Hobbes's argument in another way as well, as an attack on the republican view of liberty, which (taking a surprising twist), rather than pointing to a resulting lack of freedom for individuals in a Hobbesian commonwealth, shows instead that individuals still end up, on Hobbes's minimalist notion of liberty, with a rather extensive set of liberties.

The upshot of Hobbes's attack on the theorists of republican liberty is thus that they are wholly mistaken to suppose that we can live as free-men only in free states. On the contrary, we retain the entirety of our natural liberty even under the most absolute forms of monarchical sovereignty that can possibly be imagined. ${ }^{28}$

Skinner notes that Hobbes describes various liberties that we hold onto, including what to all intents and purposes are what he terms 'inalienable natural rights', describing them as 'liberties which fall outside the terms of the covenant' ${ }^{29}$ Where I differ from Skinner is, first, in my analysis of Hobbes's theory of rights, which I see as more central to his (Hobbes's) political theory as a whole, and with implications beyond those mentioned by Skinner. Second, as I argue here, we can find, in Hobbes's descriptions of specific rights held by individuals, evidence that he moves beyond the understanding of liberty as simply the absence of external impediments, to a more extensive understanding of liberty. So, while Skinner is convinced that Hobbes really does conceive of liberty as nothing more than the absence of external physical impediments, I argue that he is using a much broader understanding of liberty when he discusses the rights of individual subjects within a Hobbesian commonwealth.

If one focuses on Hobbes's theory of rights and the ways in which he discusses liberty in relation to the rights that we hold and to those we must carry into a commonwealth, it becomes clear, I shall argue, that Hobbes's pronouncements on liberty are not limited to those that follow what I will call the restrictive definition of liberty, that is, as nothing more than the absence of external impediments. I will make use of the distinctions made by Michael Goldsmith ${ }^{30}$ and Annabel Brett ${ }^{31}$ (in their discussions of Hobbesian liberty) between the restrictive definition and less restrictive definitions and show that Hobbes's descriptions of rights can only be rendered coherent when such expanded definitions of liberty are used.

\section{HOBBESIAN LIBERTY NOT CONFINED TO THE ABSENCE OF EXTERNAL IMPEDIMENTS}

My first argument, then, is that Hobbes (in Leviathan) uses not only the notion of liberty set out in the restrictive definition (that is, as nothing more than the absence

27 Ibid.

$28 \mathrm{Ibid}, 173$.

$29 \mathrm{Ibid}, 167$.

30 Goldsmith (n 5).

31 Brett (n 5). 
of external impediments); he also uses the notion of liberty in a broader sense. The first step in seeing where Hobbes expands on the restrictive definition is set out by Goldsmith and will be discussed below. The second step, I argue, can be seen by examining the ways in which Hobbes uses the notion of liberty in his theory of rights (in Leviathan). Once one looks at the way Hobbes describes the various rights held by individuals, it becomes clear that he is using a more extensive notion of liberty than that of the restrictive definition of the absence of 'externall Impediments of motion'. ${ }^{32}$ I shall start with some definitions as a reminder of how Hobbes explicitly defines both liberty and right, before he expands on each notion.

\section{Hobbes's Definitions}

In Chapter 14 of Leviathan Hobbes defines a right in the following way:

... they that used to speak of this subject, use to confound Jus, and Lex, Right and Law; yet they ought to be distinguished; because RIGHT, consisteth in liberty to do, or to forbeare; Whereas LAW, determineth, and bindeth to one of them: so that Law, and Right, differ as much as Obligation, and Liberty; which in one and the same matter are inconsistent. ${ }^{33}$

And in the previous paragraph he defines liberty in the following way:

By LIBERTY, is understood, according to the proper signification of the word, the absence of externall Impediments: which Impediments, may oft take away part of a mans power to do what hee would; but cannot hinder him from using the power left him, according as his judgement, and reason shall dictate to him. ${ }^{34}$

This definition of liberty, as the absence of external impediments to one's actions, is well known, as I have mentioned above, infamous even, for its stark vision of human liberty as nothing more than a purely physical freedom, a lack of being physically prevented from what I want to do or forbear from doing. The second part of the definition raises some interesting questions regarding how Hobbes might see the place of power or capacity in his understanding of liberty. ${ }^{35}$ In Chapter 21, Of the LIBERTY of Subjects, he adds the following:

LIBERTY or FREEDOME, signifieth (properly) the absence of Opposition; (by Opposition, I mean externall Impediments of motion;) and may be applied no lesse to Irrationall, and Inanimate creatures, than to Rationall. ${ }^{36}$

First, I want to draw attention to Hobbes's statement of what a right consists in. For him, a right is a freedom or liberty to do something or to forbear from doing it, and where there is a right there cannot be an obligation or duty. That is, if I have a right to $\varphi$ then I cannot have an obligation or duty not to $\varphi$. (It should be noted that this

32 Leviathan (n 2) ch 21, 261.

33 Ibid, ch 21, 189 (my emphasis).

34 Ibid (my emphasis).

35 For a discussion of this see Matthew H Kramer, 'On the Unavoidability of Actions: Quentin Skinner, Thomas Hobbes, and the Modern Doctrine of Negative Liberty' (2001) 44 Inquiry 315.

36 Leviathan (n 2) ch 21, 261. 
is not to say that my right to $\varphi$ cannot be correlated with a duty on someone else's part not to $\varphi$; just that it cannot be the case that I have both a right to $\varphi$ and a duty not to $\varphi$ ). The significance of this for the present discussion is that Hobbes defines a right as a liberty and then opposes it to obligation or duty. So, in this sense, liberty and obligation are opposites or contradictories. This is puzzling in the light of his definition of liberty as the absence of external impediments, for in what sense can a lack of external impediments be opposed to obligation? Before I attempt to answer this question I shall outline Michael Goldsmith's interpretation of Hobbes's use of the term 'liberty'.

\title{
Goldsmith's Interpretation of Hobbesian Liberty-Freedom from Civil Bonds
}

Michael Goldsmith's interpretation of Hobbesian liberty is justly famous. He demonstrates that Hobbes uses the term to cover more than just an absence of physical impediments. ${ }^{37} \mathrm{He}$ points out that in Chapter 21 of Leviathan Hobbes expands his notion of liberty to include freedom from civil bonds as well as physical ones.

But as men, for the atteyning of peace, and conservation of themselves thereby, have made an Artificial Man, which we call a Common-wealth; so also have they made Artificial Chains, called Civill Lawes, which they themselves, by mutuall covenants, have fastned at one end, to the lips of that Man, or Assembly, to whom they have given the Soveraigne Power; and at the other end to their own Ears. ${ }^{38}$

Goldsmith analyses this expansion of liberty in the following way:

\begin{abstract}
Although Hobbes emphasises the absence of physical restraint as the strict core meaning of liberty, he also allows that humans may be unfree in a different, less strict, extended sense. In contrasting the circumstances in which a person is unfree with those in which one is not unfree, Hobbes mentions situations which are described as free because the actor is not restrained by bonds imposed by law or covenant. ${ }^{39}$
\end{abstract}

This allows Hobbes to use liberty to mean freedom from law or even freedom from obligation, rather than just freedom from physical impediments. The remark Hobbes makes following that about 'Artificiall Chains' (as above) is also interesting; he says, ' $[\mathrm{T}]$ hese Bonds in their own nature but weak, may neverthelesse be made to hold, by the danger, though not by the difficulty of breaking them' ${ }^{40}$ We must be careful here because Hobbes has already denied that actions done from fear are therefore not performed freely, ${ }^{41}$ and so we are left with the problem of how we

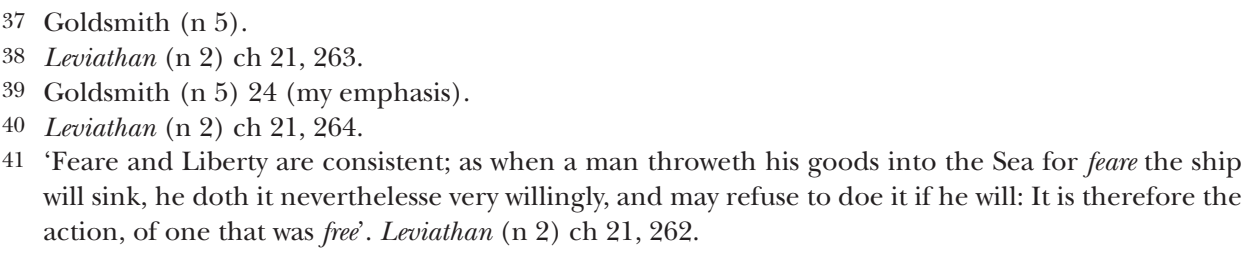

41 'Feare and Liberty are consistent; as when a man throweth his goods into the Sea for feare the ship will sink, he doth it neverthelesse very willingly, and may refuse to doe it if he will: It is therefore the action, of one that was free'. Leviathan (n 2) ch 21, 262. 
should interpret the claim that the bonds of law or obligation can restrict liberty by danger.

Perhaps the most likely thing that Hobbes has in mind is that in our deliberations we will factor in the danger of breaking such bonds (of obligation or law) and choose to restrict our own liberty. He says that in the context of the liberty of the subject we must consider what 'liberty we deny ourselves' when we make a commonwealth and decide what rights (liberties) we need to give up. Does he now mean to say that after our initial move to give up and transfer certain rights (liberties), and once we are living in a commonwealth, we will continue to make decisions about restricting our liberties in light of the danger to ourselves if we do not? One advantage of this interpretation is that it does not go against Hobbes's insistence that there is no '[o]bligation on any man, which ariseth not from some act of his own', ${ }^{42}$ and it also stresses the autonomy of the individual, in calculating how much danger is posed by the prospect of breaking a law or ignoring an obligation and then deciding whether and how much to restrict one's own liberty. This fits well with the way Hobbes characterises the voluntariness of our actions, including those that are a response to danger. If one is stuck with the restrictive definition of liberty, however, this interpretation will not work. How can I deny myself liberty if liberty is nothing but an absence of external impediments to my actions? Can I deny myself the absence of a physical impediment—can I deny myself the absence, say, of a high hedge that prevents me from walking forwards? No, the hedge denies me that absence, not I. But I can deny myself the freedom I would have were I to ignore the obligation on me to walk around people's hedges. Or I could choose not to deny myself that freedom and cut my way through it.

With Goldsmith's extended definition of liberty in mind, I will now look at some of the actual liberties that Hobbes discusses in the context of his theory of rights; rights, for example, that Hobbes says we must hold on to when we make the move from the state of nature to a commonwealth. '[T] here be some Rights, which no man can be understood by any words, or other signes, to have abandoned, or transferred.' ${ }^{43}$ The aggregate right to self-preservation, which is never given up, is a right not only to what is necessary to survive but also to "the means of so preserving life as not to be weary of it'. ${ }^{44}$ This turns out to involve a quite extensive list of liberties, which are worth considering in the context of the restrictive definition.

\section{Liberties in the Context of Hobbesian Rights}

The liberties Hobbes discusses in the context of his theory of rights are shown to vary according to the way he defines the rights that individuals have in three different sets of circumstances: ${ }^{45}$ liberties which are held in the state of nature ('a Right to every

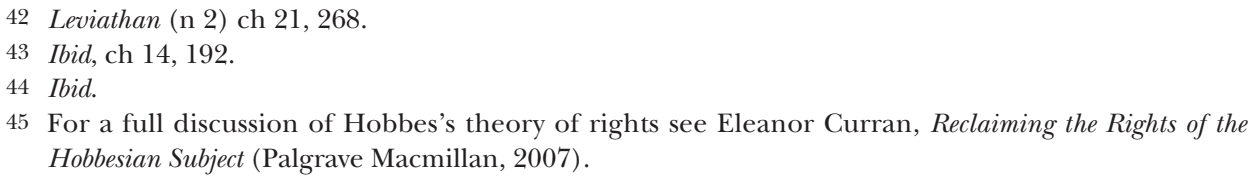


thing; even to one anothers body'46); liberties which are given up or transferred, under the second law of nature, ("[t] hat a man be willing, when others are so too, as farre-forth, as for Peace, and defence of himselfe he shall think it necessary, to lay down this right to all things; and be contented with so much liberty against other men, as he would allow other men against himselfe ${ }^{37}$ ); and liberties which are held onto and carried into the commonwealth ('there be some Rights, which no man can be understood by any words, or other signes, to have abandoned, or transferred'; 48 'every Subject has Liberty in all those things, the right whereof cannot by Covenant be transferred' 49 ).

Skinner argues (as above) that Hobbes turns his back on the rich republican tradition of liberty and replaces it with the restrictive definition of liberty, which is quite staggering in its narrowness..$^{50}$ But Hobbes (although he declares his hostility to the republican understanding of liberty ${ }^{51}$ ) does use (Hobbesian) liberty as the foundation for the rights that are so central to his argument for government. These are the rights which he thinks we enter civil society in order the better to exerciseit is our right to preserve ourselves that lies at the heart of his argument-and they are the rights for which we become obligated to obey the sovereign. In the Review and Conclusion of Leviathan he says, of submission to a victor, that individuals 'contract with the Victor, promising Obedience, for Life and Liberty' ${ }^{52}$ It is hard to see how this use of the notion of liberty by Hobbes can be reconciled with the restrictive definition of the absence of external impediments. Indeed, it would be absurd to promise obedience to a victor in return for the absence of external impediments to one's actions.

Hobbes begins his discussion of rights with a description of the right of nature, as above, according to which 'every man has a Right to every thing; even to one anothers body'. ${ }^{53}$ This untrammelled liberty protects no one and seems to allow immoral or amoral actions with its lack of restrictions in terms of what actions are allowable. The right of nature is generally taken as the exemplar of a Hobbesian right, ${ }^{54}$ and all rights in the theory are usually defined as or assumed to be Hohfeldian liberty rights or privileges ${ }^{55}$ If all rights in a Hobbesian commonwealth

46 Leviathan (n 2) ch 14, 190.

47 Ibid.

48 Ibid, ch 14, 192.

49 Ibid, ch 21, 268.

50 So, the water in a vessel literally does not have the liberty to flow out and a person in chains does not have the liberty to walk away. Leviathan (n 2) ch 21, 262.

51 Ibid, ch 21, 266-7.

52 Ibid, Rev and Concl, 721.

53 Ibid, ch 14, 190.

54 See eg Andrew I Cohen, 'Retained Liberties and Absolute Hobbesian Authorisation' (1998) XI Hobbes Studies 33; David Gauthier, The Logic of Leviathan (Clarendon, 1969); Hampton (n 9); Gregory Kavka, Hobbesian Moral and Political Theory (Princeton University Press, 1986); C Finkelstein, 'A Puzzle about Hobbes on Self-Defense' (2001) 82(3-4) Pacific Philosophical Quarterly 332.

55 See eg Conol Condron, Thomas Hobbes (Twayne, 2000), Gauthier (n 54); Hampton (n 9); Alan Ryan, 'Hobbes's Political Philosophy' in The Cambridge Companion to Hobbes (Cambridge University Press, 1996); Howard Warrender, The Political Philosophy of Hobbes: His Theory of Obligation (Clarendon, 1957). 
are liberty rights, that is, liberties with no correlative duties to protect them, then the rights he provides are, it is argued, not really rights at all; they are instead 'mere freedoms' or 'bare liberties'. The addition of' 'mere' and 'bare' in front of the word liberty or freedom has the effect of demeaning the notion of liberty to something useless and undesirable in a system of political morality; something that gives its bearers nothing that would improve their lives. This thought is clearly expressed by John Finnis in Natural Law and Natural Rights in the following passage:

Pushed as far as Hobbes's purposes, this contrast between law and rights deprives the notion of rights of virtually all its normative significance. Hobbes wishes to say that a man has most rights when he is in the 'state of nature', i.e. a vacuum of law and obligation, since 'in such a condition, every man has a right to everything (sic); even to one another's body'. But we could just as well say that in such a condition of things, where nobody has any duty not to take anything he wants, no one has any rights. ${ }^{56}$

One thing to point out here is that Hobbes himself is of course aware of this implication of the right of nature, and he spells it out in The Elements of Law when he says, 'that right of all men to all things, is in effect no better than if no man had right to any thing. For there is little use and benefit of the right a man hath, when another as strong, or stronger than himself, hath right to the same'. ${ }^{57}$ Hobbes does develop a genuine theory of rights, however, when he describes how individuals must relinquish the right to every thing of the state of nature, giving up those rights that they would not wish others to hold against them and taking on duties not to interfere with the remaining rights that each person holds on to and carries into the commonwealth. ${ }^{58}$

For my purposes here, I just want to draw attention to the nature and extent of the liberty Hobbes describes, when in various places he mentions those rights (liberties) that must not be given up when we enter a commonwealth. (Of course, it must be remembered that for Hobbes all rights are liberties, as above.) These include the liberty to: resist arrest, even when rightfully accused and taken by force; govern one's own body; have access to air and water and freedom of movement ('waies to go from place to place'); enjoy all things without which one cannot live well; ${ }^{59}$ buy and sell and make contracts; choose one's own abode, one's own diet, one's own trade of life; bring up one's children as one sees fit; and so on. ${ }^{60}$

Most of these liberties make no sense if the restrictive definition of liberty as merely the absence of external impediments is applied. Take the right (liberty), as above, to resist arrest. Clearly, if a person is being arrested and taken by force, there is not an absence of physical impediment to her resistance. Indeed, if she is being taken by force, then she is not physically free to resist that arrest. On the contrary, she is

56 John Finnis, Natural Law and Natural Rights (Oxford University Press, 1980) 208.

57 Thomas Hobbes, The Elements of Law Natural and Politic in Human Nature and De Corpore Politico (JCA Gaskin ed) (Oxford University Press, 1994) 80.

58 See Curran (n 45) ch 3.

59 Leviathan (n 2) ch 15, 212.

60 Ibid, ch 21, 264. 
being physically forced to move, and so there is a physical impediment to her standing still. Yet, Hobbes tells us that such a person has 'the Liberty to disobey' ${ }^{61}$ To get to the bottom of what Hobbes means here it is necessary to go back to the beginning of the quoted passage in Chapter 21, where he says, next to the squib 'Liberty of Subjects how to be measured', the following:

To come now to the particulars of the true Liberty of a Subject; that is to say, what are the things, which though commanded by the Soveraign, he may neverthelesse, without Injustice, refuse to do; we are to consider, what Rights we passe away, when we make a Common-wealth; or (which is all one,) what Liberty we deny our selves. ${ }^{62}$

Once again, it is difficult to make sense of this on the restrictive definition and even, in this case, on the extended definition given by Goldsmith, according to which liberty can be infringed by laws or obligations as well as by physical impediments. Here, Hobbes says we even have the 'liberty' to disobey the law (commands of the sovereign).

So, how can we make sense of the actual liberties that Hobbes lists as rights we hold on to and carry into the commonwealth? In Chapter 21 he gives two categories of such rights (liberties). First, he tells us that

[t] he Liberty of a Subject lieth ... only in those things, which in regulating their actions, the sovereign hath praetermitted: such as is the Liberty to buy, and sell, and otherwise contract with one another; to choose their own aboad, their own diet, their own trade of life, and institute their children as they themselves think fit; and the like. ${ }^{63}$

It would be very puzzling if by this Hobbes meant that we should be free from physical impediments to buy and sell and make contracts etc. In this instance we can use Goldsmith's extended definition of liberty to include freedom from civil bonds as well as physical ones. It now makes sense to say that Hobbes means that we should be free from any laws or obligations that would prevent us from buying and selling, choosing our own diet etc.

The second category of rights (liberties) that we continue to hold in the commonwealth are those rights which, as he has already explained in Chapter 14, cannot be given up because they are necessary for our preservation in a broad sense, ${ }^{64}$ that is, for our own good. ${ }^{65}$ This category consists in those rights (liberties)

61 Ibid, ch 21, 269

62 Ibid, ch 21, 268.

63 Ibid, ch 21, 264.

64 For a full discussion of the extent of the right to self-preservation that individuals hold and retain in the commonwealth see Eleanor Curran, 'Can Rights Curb the Hobbesian Sovereign? The Full Right to Self-Preservation, Duties of Sovereignty and the Limitations of Hohfeld' (2006) 25 Law and Philosophy 243.

65 Next to the squib 'Not all Rights are alienable', Hobbes says, 'Whensoever a man Transferreth his Right, or Renounceth it; it is either in consideration of some Right reciprocally transferred to himselfe; or for some other good he hopeth for thereby. For it is a voluntary act: and of the voluntary acts of every man, the object is some Good to himselfe. And therefore there be some Rights, which no man can be understood by any words, or other signes, to have abandoned, or transferred. As first a man cannot lay down the right of resisting them, that assault him by force, to take away his life; ... the same may be sayd of Wounds and Chayns, and Imprisonment'. Leviathan (n 2) ch 14, 192. 
that remain with each individual into the commonwealth so that 'every Subject has Liberty in all those things, the right whereof cannot by Covenant be transferred' ${ }^{66}$ The surprisingly extensive list of liberties Hobbes gives to the individual subject here includes the following: the right to resist those who assault him, the right to disobey the sovereign's command to 'kill, wound or mayme himself'; the right to disobey a sovereign command to 'abstain from the use of food, ayre, medicine, or any other thing, without which he cannot live'; the right not to incriminate oneself; the right to disobey the sovereign's command to execute any dangerous or dishonourable office, so long as the refusal does not frustrate the end of the institution of sovereignty itself (namely peace and security against a common enemy); and, with the same proviso, the right not to go to war.

Again, we cannot make sense of these liberties on the restrictive definition, which would force us to say that when Hobbes declares that there are things 'which though commanded by the Soveraign, he may neverthelesse, without Injustice, refuse to do', ${ }^{67}$ he means simply that there are no physical impediments to his refusing. We can make sense of these liberties, however, on the extended definition, by replacing physical impediments with the impediments of law or obligation. As Hobbes says, 'no man ... can be obliged by Covenant to accuse himselfe', ${ }^{68}$ and even the very phrases 'Liberty to disobey' and 'Liberty to refuse' cannot be made sense of in this context by using the restrictive definition, which would give us 'no physical impediments to refusal' and 'no physical impediments to disobedience'.

\section{Annabel Brett-Liberty per se and Natural Liberty}

Annabel Brett explains the apparent inconsistency between these uses of 'liberty' by drawing a distinction between what she terms Hobbes's use of 'liberty per se' and his use of 'natural liberty'. She argues that it is 'liberty per se', or corporeal liberty, that is the liberty of the definition 'absence of external impediments', and which 'became increasingly important to [Hobbes]', ${ }^{69}$ while natural liberty is derived from the 'juristic' conception of liberty and is most clearly explained in The Elements of Law. ${ }^{70}$ Brett characterises Hobbes's account of the latter in the following way:

An action is within our power to do or not to do, according to Hobbes, for as long as it is neither impossible nor done. Liberty is formally defined as the liberty to do or not to do that action; and in the process of decision-making, we habitually put an end to our own liberty. This deliberation, this relieving ourselves of our liberty, is the process that results in will: ${ }^{71}$

and Hobbes uses it to refer to the liberty of nature or the equivalent of the right of nature. So, natural liberty is the state of liberty we can fall back into if, for

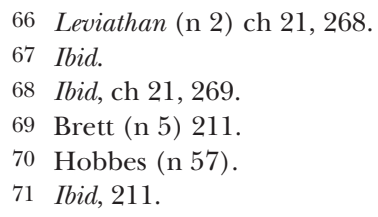


example, the monarch renounces power. ${ }^{72}$ It certainly seems difficult to understand what state of liberty we fall back into, upon the loss of a sovereign with power over us, if it is purely corporeal liberty he is referring to. Brett suggests that Hobbes does not quite know how to reconcile these two notions of liberty, and argues that 'the problems with liberty in Hobbes's political theory, which are most obvious in the famous Chapter 21 of Leviathan, spring from the incompatibility of his two lines of argument'. ${ }^{73}$

While I am sympathetic to Brett's main thesis that Hobbes uses two understandings of liberty, one of which owes more to the juristic notion of liberty, I do not follow her in thinking that the use of what she terms 'natural liberty' should be confined to descriptions of the liberties individuals have in the state of nature. If that were the case, we ought to be able to make sense of Hobbes's descriptions of those rights we hold in a commonwealth, using only liberty per se (that is, liberty understood under the restrictive definition of the absence of external impediments). Brett's explanation for why we are unable to do that, is that in Chapter 21, Hobbes's 'argument is confused'. ${ }^{74}$ She says that he wants to say that 'natural liberty' has been given up, but the argument in Chapter 21 leads him to the contradictory position that a commonwealth is actually 'a state of natural liberty'. ${ }^{75}$ She is forced to say that the inability to explain the liberties he describes in Chapter 21, on the restrictive definition, is down to 'Hobbes' failure completely to separate out corporeal liberty from natural liberty'.$^{76}$ I prefer the explanation that, in order to make sense of Hobbes's descriptions of the rights (liberties) that we bring with us into the commonwealth, we need an extended definition of liberty, as I have argued above.

\section{HOHFELD'S CLAIM AS THE ONLY RIGHT 'PROPERLY SO CALLED'}

My second line of argument concerns the influence that Hohfeld's analysis of rights in the legal literature has had on discussions of political (and moral) rights. One effect of the dominance of the notion of a claim as foundational of a political right (a dominance that exists both in Hobbes scholarship and in the work of at least some rights theorists who follow Hohfeld ${ }^{77}$ ) has been to push aside the notion of liberty. This does not happen in the analysis of legal rights, where the Hohfeldian categories are often found together in various combinations, ${ }^{78}$ but in discussions of

Ibid, 210.

3 Ibid, 211.

74 Ibid, 232.

75 Ibid, 233

76 Ibid, 232.

77 See Introduction, above.

78 See eg Matthew Kramer in Kramer, Simmonds and Steiner (n 12) 11. '[A]cts or omissions that are based on liberties can be protected quite extensively even though the liberties do not themselves place restrictions on anyone. Not only will a liberty-to-do- $\varphi$ combine sometimes with a right-to-befree-from-interference-with-the-doing-of- $\varphi$ specifically, but it often combines with other rights-such as the right to be free from physical assaults—which effectively shield the doing of $\varphi^{\prime}$. 
political rights (a good example being discussions of Hobbes's theory of rights) one effect of applying the Hohfeldian analysis is that liberties (or privileges as he called them) are then defined as mere freedoms without any protection (that is, not just without any directly correlated duties, but without any protection at all), and therefore not moral or political rights proper, but, we might say, pre-political rights or even not rights at all. Hampton is a case in point. She thinks that only 'claim rights' can be defined as 'moral rights' and that Hobbes's subjectivist moral theory means that he only includes 'liberty rights' in his political theory, rights which, having no correlative duties, are on her view not moral rights at all. ${ }^{79}$

This way of understanding and applying Hohfeld has been particularly striking in the interpretation of Hobbes's theory of rights, which, in recent decades, has been dominated by the interpretation of all Hobbesian rights as Hohfeldian liberty rights. ${ }^{80}$ Part of the problem that I am trying to point to is that the Hohfeldian analysis is sometimes mis-applied in discussions of political rights, inasmuch as 'liberties' and 'claims' are treated as separate kinds of rights rather than just different jural relations involving the various ways that rights are treated in law.

For my purposes here, I will concentrate on the broad effect of a common political analysis of rights, influenced by Hohfeld, according to which liberties are only seen as being genuine political rights either when they are protected by surrounding claim rights ${ }^{81}$ or once they are correlated with duties-and then, of course, they are no longer liberty rights, but would now be defined as claim rightswithin the Hohfeldian definitional system. ${ }^{82}$ There has been a longstanding debate about how well the Hohfeldian analysis does describe rights as we understand them, with influential arguments against Hohfeld from, for example, Joseph Raz and Neil MacCormick pitted against muscular defences of the Hohfeldian system as a logical analysis by Mathew Kramer, Nigel Simmonds and Hillel Steiner. ${ }^{83}$ Much of this debate gets entangled in arguments about the applicability of Hohfeld's definitions

79 For example, Hampton says, 'Hobbes's use of the word "right" is roughly similar to the Hohfeldian notion of a right-privilege or right-liberty ... and this liberty we have to preserve ourselves is not something that other people are obliged to respect ... Twentieth-century thinkers who talk about liberty-rights will normally link a claim-right to a person's liberty-right such that other people have a moral obligation to respect the exercise of the liberty-right. ... However, Hobbes the ethical subjectivist assumes no such natural linkage between people's liberty-rights and moral claim-rights'. Hampton (n 9) 52-53. So, for Hampton, Hobbes is not talking about 'moral rights' at all because this would mean including claim rights, to provide protection for the liberty rights.

80 See eg Cohen (n 54); Finkelstein (n 54); Gauthier (n 54); Hampton (n 9).

81 eg in a legal analysis, as described by Kramer; see $n 77$ above.

82 Hohfeld identifies four separate meanings or uses of the term 'right' as: claim, privilege (or liberty), power, and immunity. Claims, which are directly correlated with duties on the part of another or others, are, according to Hohfeld, the only rights 'most properly called a right' (Hohfeld (n 7) 39). A privilege (or liberty) is correlated with a 'no-right' and is the opposite of a duty. Hohfeld illustrates a liberty in the following way: if a person $\mathrm{X}$ owns a piece of land, then 'whereas $\mathrm{X}$ has a right or claim that $\mathrm{Y}$, the other man, should stay off the land, he himself has the privilege of entering the land; or in equivalent words, $\mathrm{X}$ does not have a duty to stay off' (ibid, 39)

83 Joseph Raz, The Concept of a Legal System (Clarendon, 1980); The Morality of Freedom (Clarendon, 1986); Neil MacCormick, 'Rights in Legislation' in PMS Hacker and Joseph Raz (eds), Law, Morality and Society (Clarendon, 1977); Legal Right and Social Democracy (Clarendon, 1982); Kramer, Simmonds and Steiner (n 12). 
to actual rights discourse, countered by defences of the logical accuracy of the Hohfeldian system. I am not intending to enter that debate; rather, I wish to sidestep it by arguing that the notion of liberty, as Hobbes uses it in his theory of rights, can do some very useful work that the notion of a claim fails to do. (What is more, and this is merely an aside, there may be implications for public discourse on rights. One possible result of stressing the correlativity between claims and duties, and of conceptualising rights purely as claims or entitlements, is that rights will be crystallised in many people's minds as special entitlements, rather than as freedoms held by all.)

On a Hobbesian theory of rights, the same foundational concept of liberty is used throughout. By taking natural liberty as its starting point, each individual can be seen as having, as it were, a complete set of liberties (rights) initially. From this complete set (that is, on Hobbes's account, from the state of nature where we have 'a Right to every thing; even to one anothers body'84) we start a process of giving up and transferring rights to one another. So, for example, I transfer my right to your body over to you, not giving you a right you didn't have before but agreeing to refrain from any future interference with your right and thereby providing you with some protection (of your right) ${ }^{85}$ All such invasive rights must be given up or transferred, and of our remaining rights we must also decide which ones we must not or cannot give up or transfer. These will be those rights "without which a man cannot live, or not live well'. ${ }^{86}$ So, curtailments of our freedom will only be acceptable if they do not harm our ability to live or, indeed, to live well.

There is an elegance and simplicity to this way of seeing rights: elegance because the foundational notion of liberty is used throughout, and simplicity because the use of the notion of liberty attaches each right firmly to its holder and keeps it separate from any accompanying duties of others. It also makes the starting point of rights each individual's desire for freedom rather than claims on the duties of others. My argument is that the notion of liberty, as used by Hobbes, (in an extended way rather than according to the restrictive definition) captures an important aspect of what we understand in everyday discourse about rights, and allows us to find more flexible and simple ways of discussing political and moral rights and their protection. For example, in Hobbes's theory of rights, by using the notion of liberty to define a right, he is able to discuss a range of rights-from the unrestricted and unprotected freedoms of the state of nature to the inalienable and somewhat protected rights held within a commonwealth. The protection or lack of protection for each right can be incorporated into the description of that right (liberty). In other words, it differs from a (mis)application of a Hohfeldian analysis (of liberties and claims),

84 Leviathan (n 2) ch 14, 190.

85 '.. and when a man hath ... granted away his Right; then is he said to be OBLIGED, or BOUND, not to hinder those, to whom such Right is granted, ... from the benefit of it: and that he Ought, and it is his DUTY, not to make voyd that voluntary act of his own'. Leviathan (n 2) ch 14, 191.

86 'As it is necessary for all men that seek peace, to lay down certaine Rights of Nature; that is to say, not to have libertie to do all they list: so it is necessarie for mans life to retaine some; as right to governe their owne bodies; enjoy aire, water, motion, waies to go from place to place; and all things else without which a man cannot live, or not live well'. Leviathan (n 2) ch 21, 212. 
according to which the right itself will be defined according to its protection or lack thereof. On that interpretation of a Hohfeldian analysis, if it lacks protection of any sort then it will be a (bare) liberty right. If it is protected by the duties of others then it will be a (moral/political) claim right.

I should make it clear that I am not trying to dispute the logical accuracy or the analytical brilliance of Hohfeld's scheme as an analysis of legal rights. Rather, I am arguing, first, against his proposal that the 'claim right' is the only one of his definitions that may properly be called a right, and, second, that the resulting tendency among some writers discussing political rights (such as those discussing Hobbes's theory of rights) to assume or argue that all political rights are claim rights, restricts those discussions in an unhelpful way. It is in the application of a Hohfeldian analysis to discussions of political rights that these sorts of problems arise. Hohfeld's analysis is designed to explain the treatment of relations between people, by the law, in situations where we can say, broadly, that their legal rights are affected. In this analysis a person's power to change her legal position, for example in relation to a will, are included, while such rights have no specific importance in discussions of political rights. And, as I have said, in the legal analysis, liberty rights exist within a context of surrounding claim rights, and so are never, as it were, wholly unprotected.

Before I can discuss these arguments in any more detail, some definitions might be useful. According to the Hohfeldian analysis of rights in the legal literature, the word 'right' can be used in four ways. It can refer to a claim, a privilege (or liberty), a power, or an immunity. It is only the first of these, a claim, that is really deserving of the title 'right', according to Hohfeld, because it describes 'that legal relation which is most properly called a right or claim' 87 and which is 'a right in the strictest sense' ${ }^{88}$. The four categories of legal relations involving rights are each shown to have legal correlatives and legal opposites (or contradictories), and for my purposes here I only need two categories of right, or uses of the term 'right', namely that of a claim and that of a liberty (or privilege), as set out in the table below.

Hohfeldian Analysis of Claim Right and Liberty Right (or Privilege)

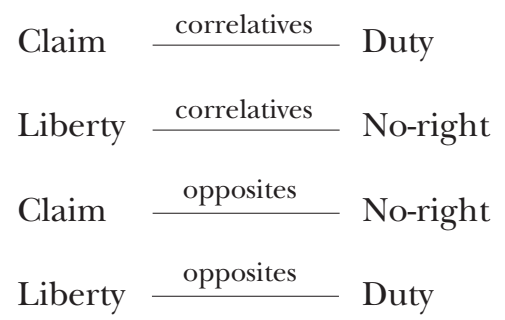

87 Hohfeld (n 7) 39 .

88 Ibid, 36. 
So, a claim on the part of $\mathrm{X}$ re $\mathrm{A}$ is always correlated with a duty on the part of at least one other (ie a duty to allow or provide or help, such as the duty of $\mathrm{Y}$ to allow $\mathrm{X} \mathrm{A}$, or help X to have A, or to give X A), and the contradictory of X's claim right re $\mathrm{A}$ is that $\mathrm{X}$ does not have a no-right (ie no claim) re A. And a liberty on the part of $\mathrm{X}$ re A is correlated with a no-right of someone re A (ie Y, say, has no claim that $\mathrm{X}$ should not have $\mathrm{A}$ or do A), and the contradictory of X's liberty re $\mathrm{A}$ is that $\mathrm{X}$ has no duty to do A or have A or to not do A.

An example might stick better in the mind. If I have a right to walk down my garden, then I am free to walk down my garden and it cannot be the case that I have a duty to not walk down my garden. So, there is the absence of an obligation (I am using duty and obligation interchangeably) not to walk down my garden and a freedom/liberty to do so. So far, there is no mention of any protection for this right. In other words, it is not the case that any or all other people are under an obligation to allow me to walk down it/not interfere with my walking down it. This is what Hohfeld defines as a liberty right (or privilege). On the other hand, if Y appears in my garden, she does not have a right to walk down it and I have a right that she should not do so. I have a right to my garden against $Y$ such that she has a duty to stay out of it (unless I have invited her in or opened it up to the public to view my beautiful flowers). This is what Hohfeld defines as a claim. So, my claim to my garden is correlated with everyone else's duty to stay out of it.

When we are talking about legal rights, it can be seen that such rights are often bundles of different Hohfeldian rights, such as above, where I have (at least) liberty rights and claim rights in relation to my garden. But when political or moral rights are being discussed (and it is now accepted by many that the Hohfeldian analysis applies to political rights as well as to legal rights) ${ }^{89}$ then it is usually the claim right alone that is taken to be properly called a right. A consequence of this is that only rights which have directly correlative duties are deemed rights in a political sense, and rights which do not have such duties, for example what Hohfeld calls privileges and most commentators refer to as liberty rights, as they lack such correlative duties, cannot be deemed full rights in a political sense. As I mentioned above, Jean Hampton, in her analysis of Hobbesian rights, is a good example of this. Another is Claire Finkelstein, who, in discussing Hobbes's right to self-defence, says, '[f] or Hobbes' right to self-defense is a mere liberty right, rather than a fully-fledged claim right. That is, it is a right that places no one under a correlative duty of noninterference'. ${ }^{90}$

That is one aspect of the problem; a set of rights, such as my right to walk down my garden (at least when discussed as a moral or political right rather than as a legal right), fall out of the definition of a (full moral or political) right, on this view. Another aspect of the problem is that instead of discussing and understanding moral or political rights as freedoms or liberties, we discuss and understand moral and political rights only as claims.

89 See eg Jeremy Waldron (ed), Theories of Rights (Oxford University Press, 1984); Matthew Kramer in Kramer, Simmonds and Steiner (n 12).

90 Finkelstein (n 54) 358 (my emphasis). 


\section{CONCLUSION: LIBERTIES NOT CLAIMS SHOULD BE THE FOUNDATION FOR RIGHTS}

I agree with Mathew Kramer when he says that Hohfeld's analysis of rights, into the eight 'incidents' or relations of legal correlatives and legal 'opposites' or contradictories, is stipulative and definitional in nature and, therefore, cannot be challenged with empirical counterexamples. ${ }^{91}$ But when Hohfeld states that a 'claim' with its correlate duty is 'that legal relation most properly called a right ${ }^{\text {'92 }}$ he has moved beyond stipulative definition; now he is saying something substantive. In other words, when he declares that of the four uses of the term 'right' in his analytical scheme (namely, claim, privilege or liberty, power and immunity) it is 'claim' that most successfully captures what we mean by 'a right', he has turned from stipulative definition to substantive analysis. He is now commenting on the way in which the term 'right' is used and understood in rights discourse, and he might be going even further and saying something about the place of a right within a system of political values. It could of course be argued that Hohfeld means to say nothing more than 'a claim is what we most often refer to when talking about legal rights'. I think it is more likely, however, that what lies behind these statements is the thought that in discussions of people's rights (moral and political as well as legal), the notion of a right is often closely associated with the idea that others should respect that right; that there are duties that are correlated with a right. This also echoes an older argument in moral theory, namely, that rights are nothing more than what is implied by certain duties. ${ }^{93}$

My disagreement is with this substantive analysis, not with the stipulative definitions and the logical relations between them. I am suggesting that Hobbes's use of liberty, rather than claim, to define a right-('right consisteth in liberty to do or to forbeare ${ }^{94}$ ) enables him to describe rights using the very broad category of freedom, including freedoms we should not have (from a moral or political point of view); as well as to describe rights that are unprotected, protected by correlative duties, or protected indirectly (that is, we can talk about the protection of rights much more broadly than we can if we are restricted to using the notion of a claim).

There is not the space here to provide what would be needed in order to argue in any detail for the use of the notion of liberty, rather than that of claim, to ground the notion of a (moral or political) right. I have only been able to gesture towards some reasons why this might be profitable. By using liberty as our foundational concept for rights, we are able to talk about rights more broadly and without being tied into the correlativity of duties. Applying the Hohfeldian analysis, on the other hand, in the way it is employed in the examples given above, restricts us to describing only those rights that are claims correlated with duties to protect them,

91 Matthew Kramer in Kramer, Simmonds and Steiner (n 12) 23.

92 Hohfeld (n 7) 39.

93 For example, Warrender says: "A "right", as the term is used in moral and political philosophy, means something to which one is morally entitled. In this sense, it is used as a comprehensive description of the duties of other people towards oneself in some particular respect.' Warrender (n 55) 18.

94 Leviathan (n 2) ch 14, 189. 
and precludes, I argue, a number of liberties that we might think of as rights. I hope I have demonstrated something of the elegance and simplicity of Hobbes's use of the notion of liberty to define a right and also something of the flexibility of liberty when used as the foundational notion for a right. Equally, I have tried to show that when moral and political philosophers take the Hohfeldian 'claim' to be foundational for our notion of a (moral and political) right they are restricting themselves in ways that may be unhelpful. Putting these two lines of argument together suggests that it might be worth exploring the possibility that while dividing off the notion of liberty from that of a claim may be very useful when dealing with rights in the legal literature, it is perhaps less so when addressing moral and political rights. 